\title{
Effects of aluminum on plant growth and nutrient uptake in young physic nut plants
}

\section{Efeitos do alumínio no crescimento e na absorção de nutrientes em plantas jovens de pinhão-manso}

\author{
Fábio Steiner ${ }^{1 *}$; Tiago Zoz ${ }^{1}$; Artur Soares Pinto Junior ${ }^{2}$; \\ Deise Dalazen Castagnara ${ }^{2}$; João Alexandre Lopes Dranski ${ }^{2}$
}

\begin{abstract}
Aluminum $\left(\mathrm{Al}^{3+}\right)$ toxicity is a major limiting factor to crop productivity in acid soils. The effects of aluminum on root and shoot growth of physic nut (Jatropha curcas L.) young plants and, the uptake and distribution of phosphorus, calcium, magnesium and aluminum in the roots and shoots were investigated in the present study. Plants were grown in $2.5 \mathrm{~L}$ pots in a greenhouse. After fourteen days of adaptation to nutrient solution, plants were exposed to $\mathrm{Al}$ concentrations of $0,370,740,1,100$ and $1,480 \mu \mathrm{mol} \mathrm{L}{ }^{-1}$, corresponding to an active $\mathrm{Al}^{3+}$ solution of $13.3,35.3,90.0,153.3$ and $220.7 \mu \mathrm{mol} \mathrm{L}^{-1}$, respectively. The dry matter partitioning between roots, stems and leaves, and the concentrations of $\mathrm{P}$, $\mathrm{Ca}, \mathrm{Mg}$ and $\mathrm{Al}$ in plant tissue, were measured after 75 days exposure to $\mathrm{Al}$. The increasing level of $\mathrm{Al}^{3+}$ activity in solution progressively decreased the growth of the shoot and root of physic nut plants, and at the two highest active $\mathrm{Al}^{3+}$ levels, plants showed morphological abnormalities typical of the toxicity caused by this metal. Higher $\mathrm{Al}^{3+}$ activity reduced $\mathrm{P}$ concentrations in leaves and $\mathrm{Ca}$ and $\mathrm{Mg}$ in leaves and roots of physic nut, demonstrating the effect of $\mathrm{Al}$ on the uptake, transport and use of these nutrients by plants. The $\mathrm{Al}$ accumulated preferentially in the roots of physic nut, whereas only a small amount was transported to shoots.
\end{abstract}

Key words: Jatropha curcas, aluminum toxicity, aluminum tolerance

\section{Resumo}

A toxicidade de alumínio $\left(\mathrm{Al}^{3+}\right)$ é um dos principais fatores que limitam a produtividade das culturas em solos ácidos. O objetivo deste estudo foi avaliar o efeito do alumínio no crescimento e na absorção de fósforo, cálcio, magnésio e alumínio em plantas jovens de pinhão-manso, cultivadas em solução nutritiva. $\mathrm{O}$ experimento foi conduzido em vasos de $2,5 \mathrm{~L}$ e as plantas crescidas em casa de vegetação. Após 14 dias de adaptação em solução nutritiva, as plantas foram submetidas a concentrações de $\mathrm{Al}$ de: $0 ; 370 ; 740 ; 1.110$ e $1.480 \mu \mathrm{mol} \mathrm{L}^{-1}$, que corresponderam a atividade de $\mathrm{Al}^{3+}$ em solução de: 13,$3 ; 35,3$; 90,$0 ; 153,3$ e $220,7 \mu \mathrm{mol} \mathrm{L}^{-1}$ de $\mathrm{Al}^{3+}$, respectivamente. A partição de matéria seca entre raízes, caule e folhas e os teores de $\mathrm{P}, \mathrm{Ca}, \mathrm{Mg}$ e $\mathrm{Al}$ no tecido vegetal foram avaliados após 75 dias de exposição ao $\mathrm{Al}$. $\mathrm{O}$ aumento da atividade de $\mathrm{Al}^{3+}$ em solução diminuiu progressivamente o crescimento da parte aérea e das raízes das plantas de pinhão-manso, sendo que nas duas maiores atividades de $\mathrm{Al}^{3+}$ as plantas apresentaram anormalidades morfológicas típicas de injúria provocada por esse metal. $\mathrm{O}$ aumento da atividade de $\mathrm{Al}^{3+}$ reduziu os teores de $\mathrm{P}$ nas folhas e de $\mathrm{Ca}$ e $\mathrm{Mg}$ nas folhas e raízes do pinhão-manso

\footnotetext{
${ }^{1}$ Discente(s) de Pós-Graduação em Agronomia do Dept ${ }^{\circ}$ de Produção Vegetal. Faculdade de Ciências Agronômicas, FCA, Universidade Estadual Paulista Júlio de Mesquita Filho, UNESP. Botucatu, SP. E-mail: fsteiner@fca.unesp.br; tiagozoz@fca. unesp.br

${ }^{2}$ Discente(s) de Pós-Graduação, Centro de Ciências Agrárias, Universidade Estadual do Oeste do Paraná, UNIOESTE, Marechal Cândido Rondon, PR. E-mail: pitaspj@yahoo.com.br; deisecastagnara@yahoo.com.br; joaodranski@yahoo.com.br

* Author for corespondence
} 
reportando o efeito do $\mathrm{Al}$ na absorção, transporte e utilização destes nutrientes pelas plantas. $\mathrm{O} \mathrm{Al}$ acumulou-se, preferencialmente, no sistema radicular do pinhão-manso, sendo pequena a quantidade transportada para a parte aérea.

Palavras-chave: Jatropha curcas, toxicidade de alumínio, tolerância ao alumínio

\section{Introduction}

Physic nut (Jatropha curcas L.) is a native species to tropical America and belongs to the family Euphorbiaceae. This species is widely distributed in tropical areas, both wild and cultivated, in Central and South America, Africa, India, Southeast Asia and Australia (KING et al., 2009). In the last years, it has received special attention due to its high seed oil content and quality, which can be converted into biodiesel by the industry (ARRUDA et al., 2004; KUMAR; SHARMA, 2008).

Physic nut grows in environments with constraining conditions, such as reduced rainfall, high temperatures, poor soil conditions, where most of the agriculturally important plant species are not able to grow satisfactorily (FRANCIS; EDINGER; BECKER, 2005). However, to achieve high yield levels, plant requires fertile soils and good physical conditions (KUMAR; SHARMA, 2008). According to Arruda et al. (2004), in acid soils with $\mathrm{pH}$ below 4.5 , roots of physic nut do not grow. Thus, the acidity correction and soil fertility are critical for success and profitability in this culture (LAVIOLA; DIAS, 2008; SOUZA et al., 2011). This finding becomes even more relevant because the main producing regions of physic nut in Brazil are located in acid soils, characterized by low base saturation and high aluminum $\left(\mathrm{Al}^{3+}\right)$ levels, sufficient to alter the normal growth of many species of cultivated plants.

Aluminum toxicity is considered one of the main factors limiting plant growth in acidic soils of tropical regions, mainly by inhibiting root growth (GIANNAKOULA et al., 2008). In Brazil, toxic levels of aluminum are present in $60 \%$ of areas with agricultural potential (SÁNCHEZ; SALINAS, 1981). Thus, knowledge and selection of species less susceptible to the deleterious effects of aluminum is an alternative to the deployment of crops in agricultural areas with these conditions of fertility.

Several studies have been conducted using nutrient solutions to determine the $\mathrm{Al}$ tolerance of perennial species (BRACCINI et al., 1998a; DANTAS et al., 2001; TECCHIO et al., 2006; MATTIELLO et al., 2008; MACEDO et al., 2011). Aluminum toxicity manifests initially as a reduced rate of root elongation after contact with a solution containing Al (HARTWIG et al., 2007), and drastic reduction in shoot growth (BEUTLER; FERNANDES; FAQUIN, 2001). Phytotoxic effects of $\mathrm{Al}$ on roots include reductions in dry matter yield, the number and length of lateral roots, and root area, which are often associated with increases in the mean root diameter and root volume (BARCELÓ; POSCHENRIEDER, 2002; HARTWIG et al., 2007). The damage to the root system results in exploitation of a smaller volume of soil by the plants and losses in nutrient uptake and utilization of soil water. Research results have shown that Al negatively affects the uptake of essential nutrients such as phosphorus $(\mathrm{P})$, calcium $(\mathrm{Ca})$ and magnesium (Mg) (LÓPEZ-BUCIO et al., 2000).

Studies with castor beans, species also belonging to the family Euphorbiaceae, reported high sensitivity of this species to the presence of exchangeable Al in soil (LIMA et al., 2007). Studies of physic nut plants are still rare and inconclusive. Macedo et al. (2011) found that the presence of Al in nutrient solution affected only the root growth of physic nut plants, and had no effect on shoot growth. However, in this study, plants were grown in the presence of Al for only seven days and, because physic nut is a perennial species, responsiveness to environmental change is slow. Thus, the 
deleterious effects resulting from Al toxicity may have been minimized. An improved understanding of physic nut $\mathrm{Al}$ tolerance is essential in order to adopt competitive strategies for improving crop production. The present study analyzes the effect of aluminum on growth and uptake of $\mathrm{P}, \mathrm{Ca}, \mathrm{Mg}$ and Al on young physic nut (Jatropha curcas L.) plants grown in nutrient solution.

\section{Material and Methods}

The experiment was carried out under greenhouse conditions, where the environmental conditions were: minimum and maximum mean air temperature of 18 and $34^{\circ} \mathrm{C}$, respectively; mean air relative humidity of $65 \%$. Jatropha curcas L. seeds, collected directly from the treetop of a plant population in Marechal Cândido Rondon, Paraná

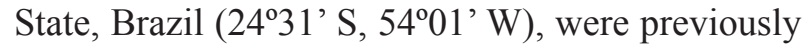
selected taking into account the seed size and weight. Afterwards, seeds were germinated in sand. Twelve days after germination in sand, seedlings were transferred to plastic pots $(2.5 \mathrm{~L})$, containing Hoagland and Arnon (1950) nutrient solution ( $\mathrm{pH}$ 6.0) with one-quarter strength in the first week and full strength thereafter.

After fourteen days of adaptation to nutrient solution, plants were exposed to Al concentrations of $0,370,740,1,100$ and 1,480 $\mu \mathrm{mol} \mathrm{L}^{-1}$, corresponding to an active $\mathrm{Al}^{3+}$ solution, estimated by the software Visual MINTEQ 3.0 (GUSTAFSSON, 2012) of: 13.3, 35.3, 90.0, 153.3 and $220.7 \mu \mathrm{mol}$ $\mathrm{L}^{-1}$, respectively. Aluminum was added in form of $\mathrm{AlCl}_{3} \cdot 6 \mathrm{H}_{2} \mathrm{O}$. The $\mathrm{pH}$ of the solution $(4.1 \pm 0.1)$ was monitored daily, and adjusted when necessary using $0.5 \mathrm{~mol} \mathrm{~L}^{-1} \mathrm{NaOH}$ or $0.5 \mathrm{~mol} \mathrm{~L}^{-1} \mathrm{HCl}$ solutions. During the experiment, the nutrient solutions, under constant aeration, were changed every 15 days and the volume in each pot was complemented daily with deionized water.

After 75 days exposure to $\mathrm{Al}$, the plants in all treatments were harvested and separated into roots, stems and leaves. The plant parts were removed carefully and washed with deionized water, dried for four days at $65^{\circ} \mathrm{C}$, and then weighed. The root and shoot lengths were measured (centimeter plant) using meter scale. The leaf area (LA, dm ${ }^{2}$ plant $^{-1}$ ) was determined using the following equation proposed by Severino, Vale and Beltrão (2007): LA $=0.84(\mathrm{~L} \times \mathrm{W})^{0.99}$, where $\mathrm{L}$ and $\mathrm{W}$ are leaf length and width, respectively. The leaf, stem and root material was ground, digested in nitric-perchloric acid, and the $\mathrm{Ca}$ and $\mathrm{Mg}$ content was determined by flame atomic absorption spectrophotometry, and $\mathrm{P}$ content was determined by colorimetry at $725 \mathrm{~nm}$ wave length, as previously described (MALAVOLTA; VITTI; OLIVEIRA, 1997). Aluminum content was determined by spectrophotometry with Eriochrome cyanine R, as described by Miyazawa et al. (1999). The amount of Al accumulated in leaf, stem and root was calculated from the dry mass of each plant part and its $\mathrm{Al}$ content in dry matter.

The experiment was arranged in a completely randomized design with five replicates (an individual pot containing one plant represented one replicate). Data were subjected to analysis of variance (ANOVA); regression analysis was carried out by $\mathrm{F}$ test for variables that presented a significant difference $(p<0.05)$ between treatments. The significant equations with the greatest determination coefficients were adjusted. All analyses were performed using SigmaPlot 11.0 software for Windows (Systat Software, Inc., San Jose, CA, USA).

\section{Results and Discussion}

The plant shoot growth of physic nut was negatively affected by the presence of Al (Figure 1). Increasing levels of $\mathrm{Al}^{3+}$ activity in solution linearly decreased the plant height, leaf area and dry matter production. The phytotoxic effect of this metal in plant development was reflected in the lowest shoot growth at the highest level of active $\mathrm{Al}^{3+}$ in solution. According to Beutler, Fernandes and Faquin (2001), among the effects of Al toxicity on shoots was a reduction in the height and dry matter production of plants. 
Figure 1. Effects of aluminum activity in nutrient solution on plant height (A), leaf area (B) and shoot dry matter (C) of young physic nut (Jatropha curcas L.) plants. Measurements were taken after 75 days of exposure to stressful conditions. Data refer to mean values $(\mathrm{n}=5)$. **: statistical significance at $1 \%$ by $\mathrm{F}$ test.
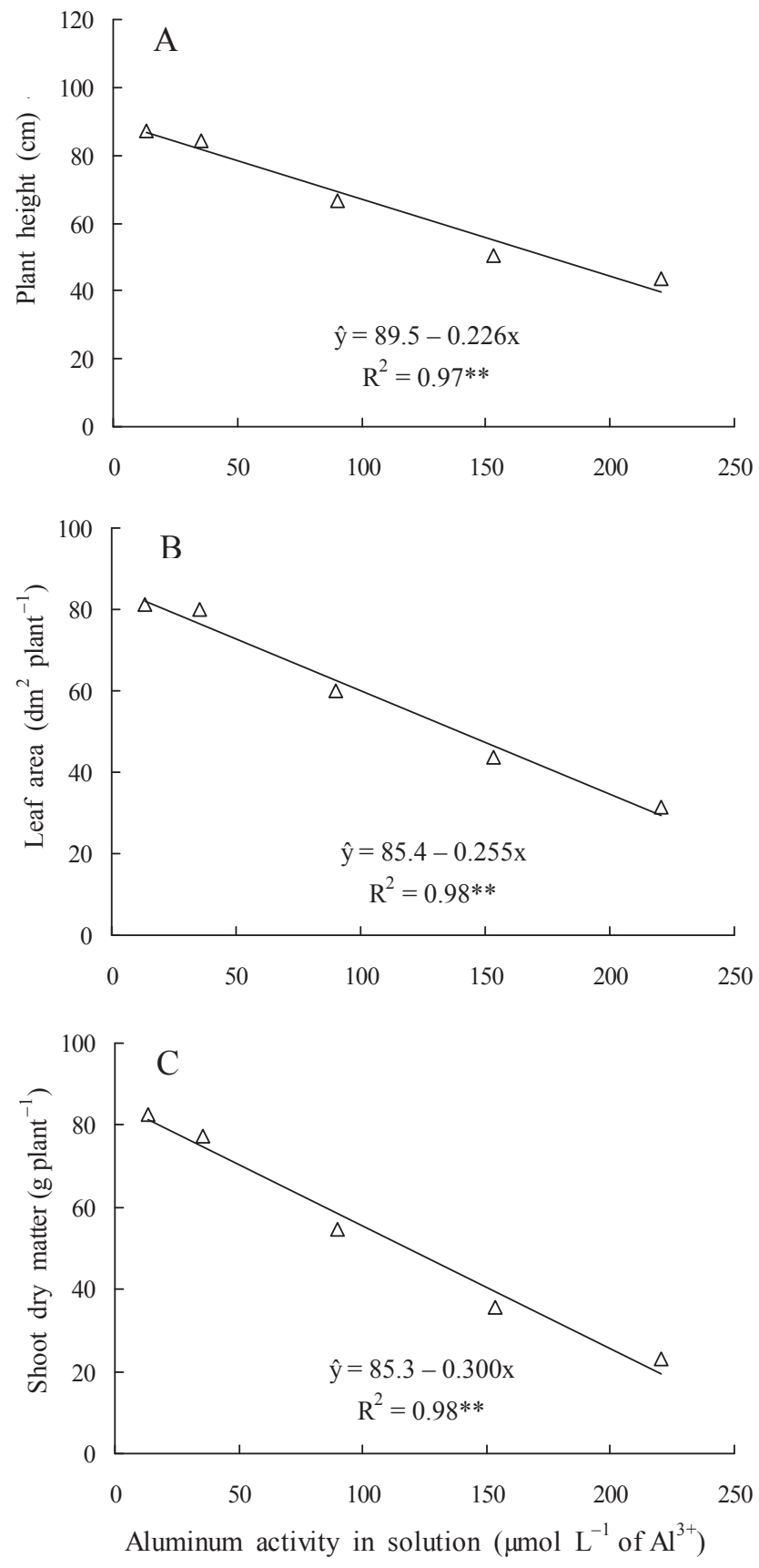

Source: Elaboration of the authors.

In coffee (BRACCINI et al., 1998a) and apple In this study of physic nut plants, plant height was the (DANTAS et al., 2001) plants, one of the main characteristic of shoots that was least affected, with effects of $\mathrm{Al}$ in the shoot was the shortening of a 54\% decrease when comparing plants exposed internodes, resulting in plants with reduced height. $\quad$ to solutions of 13.3 and $220.7 \mu \mathrm{mol} \mathrm{L}-1$ active $\mathrm{Al}^{3+}$ 
(Figure 1a). For leaf area and shoot dry matter, this decrease was $64 \%$ and $76 \%$, respectively, when comparing plants exposed to 13.3 and $220.7 \mu \mathrm{mol}$ $\mathrm{L}^{-1}$ of $\mathrm{Al}^{3+}$ (Figure $1 \mathrm{~b}, \mathrm{c}$ ). Our findings are similar to those reported for apple rootstocks (TECCHIO et al., 2006), where reductions of $65 \%$ in leaf number, $81 \%$ in plant height, and $85 \%$ in the dry matter of shoots were observed at $1.110 \mu \mathrm{mol} \mathrm{L} \mathrm{L}^{-1} \mathrm{Al}$ in nutrient solution after 75 days.

The root length (Figure $2 a$ ) and root dry matter (Figure $2 b$ ) of physic nut decreased progressively with increasing levels of $\mathrm{Al}^{3+}$ activity in solution. When the plants were exposed to active $\mathrm{Al}^{3+}$ of 153.3 and $220.7 \mu \mathrm{mol} \mathrm{L}{ }^{-1}$, there was practically no root growth. The percentage reduction in root length and root dry matter was $74 \%$ and $57 \%$, respectively, when comparing the growth of plants exposed to active $\mathrm{Al}^{3+}$ of 13.3 and $220.7 \mu \mathrm{mol} \mathrm{L}-1$ (Figure 2a, b). A major reported effect of $\mathrm{Al}$ is the inhibition of root growth, where roots become short and thick (BARCELÓ; POSCHENRIEDER, 2002). This feature, incidentally, serves as the best indicator to assess the tolerance of a species to $\mathrm{Al}$ in nutrient solution. However, a tolerance index based only on root elongation may not be the best indicator of Al tolerance (MASSOT; POSCHENRIEDER; BARCELÓ, 1992). The growth of shoots should be considered, since damage to the root system may result in reduced shoot growth. In agreement with this, Braccini et al. (1998a) found that the percentage reduction in the dry mass of shoots and roots were more appropriate characteristics to classify the genotypes of coffee according to Al tolerance. They also reported that when a reduction in the dry mass of shoots and roots was greater than $40 \%$, the genotype in question was classified as sensitive to Al. Based on these data and the results presented here, we infer that the genotype of physic nut plants used in this study is sensitive to Al toxicity. Another species belonging to the same family (Euphorbiaceae) as physic nut, the castor bean, is also high sensitive to Al (LIMA et al., 2007).
Plants exposed to the higher active $\mathrm{Al}^{3+}$ levels (153.3 and $220.7 \mu \mathrm{mol} \mathrm{L}^{-1}$ ) showed characteristic symptoms of $\mathrm{Al}$ toxicity. The young leaves were small, chlorotic, with small necrotic spots on the border, and with the typical appearance of winding. On the other hand, the older leaves had marginal chlorosis, which progressed to the center of the lamina. In roots, the symptoms of Al toxicity were quite evident, manifested by a delay and/ or an inhibition of lengthening of the main shaft, thickening of the tips of the roots, reduction of the number of lateral roots, and yellowing of the roots. These symptoms of Al toxicity in the leaves and roots of physic nut were similar to those reported in coffee plants (BRACCINI et al., 1998a).

In general, the deleterious effects of $\mathrm{Al}$ are most evident in the roots and can be attributed to the low mobility of this metal in the plant (MASSOT; POSCHENRIEDER; BARCELÓ, 1992). The damage to the structure of roots - an increase in diameter and a decrease in the permeability of root cells - accentuates the deleterious effects of $\mathrm{Al}$ on the root system (BARCELÓ; POSCHENRIEDER, 2002). Moreover, as the roots are the organs in direct contact with the nutrient solution, they are more likely to be affected by stressful factors in this environment. The effects of $\mathrm{Al}$ on roots are well documented in the literature, and the reduction in root growth (elongation and cell division) of susceptible species has been considered the main effect of toxic levels of Al (MENGEL; KIRKBY, 2001). Consistent with this interpretation, Samac and Tesfaye (2003) found that the primary site of the toxic action of $\mathrm{Al}$ is the distal part of the transition zone at the apex of the roots, where the cells are entering the elongation phase. Inhibition of root growth is the most visible symptom of Al toxicity in plants (SAMAC; TESFAYE, 2003; HARTWIG et al., 2007). 
Figure 2. Effects of aluminum activity in nutrient solution on the length of longest roots (A) and root dry matter (B) of young physic nut (Jatropha curcas L.) plants. Measurements were taken after 75 days of exposure to stressful conditions. Data refer to mean values $(\mathrm{n}=5)$. **: statistical significance at $1 \%$ by $\mathrm{F}$ test.
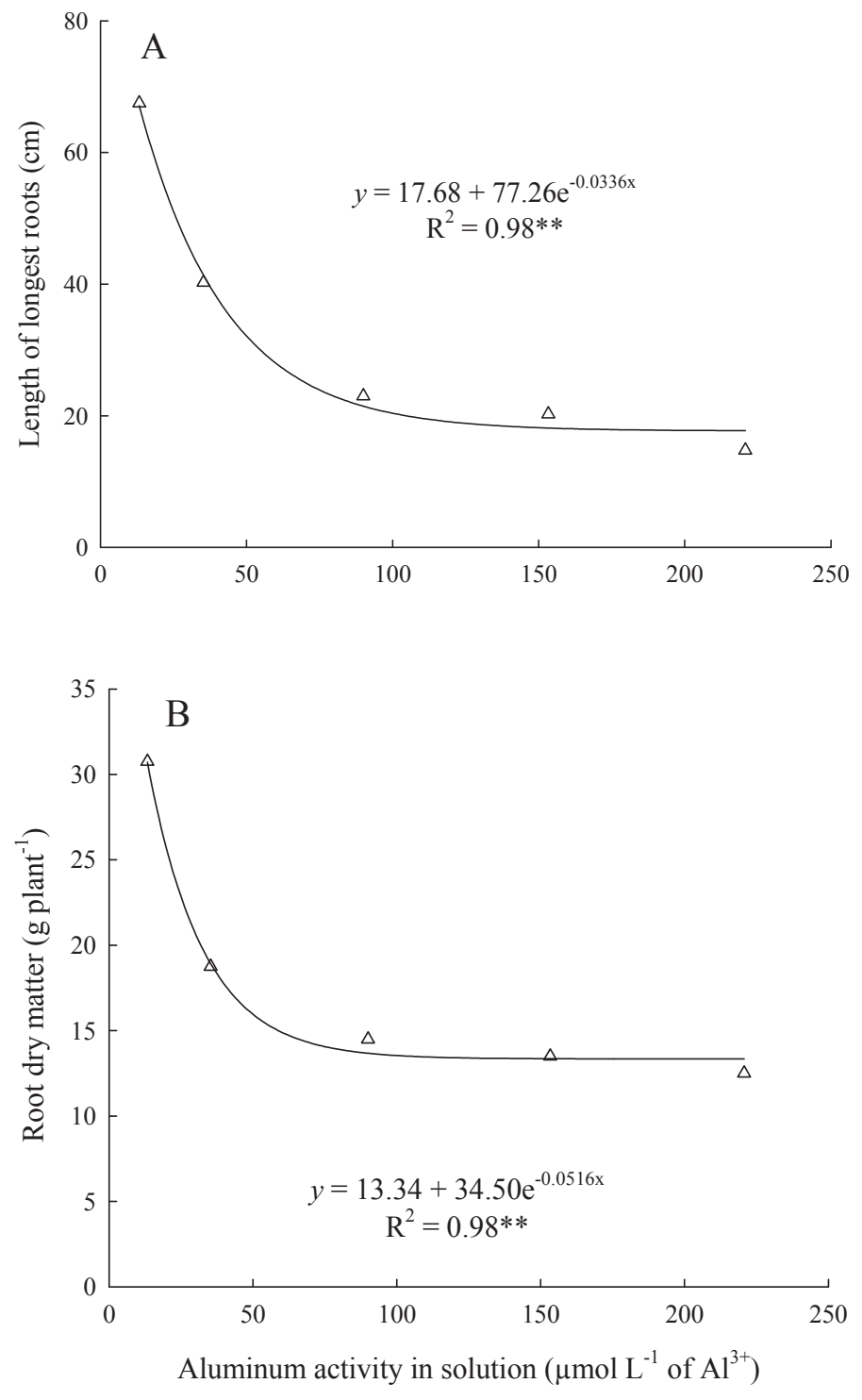

Source: Elaboration of the authors.

These morphological anomalies and the damage to root systems result in the exploration of a reduced volume of soil by plants, with consequent losses in nutrient uptake and soil water utilization. As a result, the ability of plants to acquire nutrients in the presence of $\mathrm{Al}$, especially $\mathrm{P}, \mathrm{Ca}$ and $\mathrm{Mg}$, has been interpreted as differing tolerances to this metal between plant species (BRACCINI et al., 1998b; LÓPEZ-BUCIO et al., 2000).

Increasing the active $\mathrm{Al}^{3+}$ in solution decreased the concentration of $\mathrm{P}$ in the leaves of physic nut (Table 1). There was an average reduction in $\mathrm{P}$ levels of $52 \%$ between plants exposed to 13.3 and $220.7 \mu \mathrm{mol} \mathrm{L}{ }^{-1}$ of $\mathrm{Al}^{3+}$. In roots, the $\mathrm{P}$ content was 
not affected by the presence of Al (Table 1). The higher $\mathrm{P}$ content measured in the roots of physic nut (Table 1) is due to the fact that the $\mathrm{Al}$ precipitates with the $\mathrm{P}$ in root apoplast, reducing translocation to shoots (GIANNAKOULA et al., 2008). Studies suggest that this interaction occurs in the cell wall and outside the cell plasma membrane of the root cap (McCORMICK; BORDEN, 1974), or in the vacuole of the root cells (MACKLON; SIM, 1992). Furthermore, Al can reduce the solubility of P, making it less available to plants (PAVAN; BINGHAM, 1982).

Table 1. Effects of aluminum activity in nutrient solution on the phosphorus, calcium and magnesium content of the leaves and roots of young physic nut (Jatropha curcas L.) plants. Data refer to mean values $(\mathrm{n}=5)$.

\begin{tabular}{|c|c|c|c|c|c|c|}
\hline \multirow{2}{*}{ Aluminum activity } & \multicolumn{2}{|c|}{ Phosphorus } & \multicolumn{2}{|c|}{ Calcium } & \multicolumn{2}{|c|}{ Magnesium } \\
\hline & Leaf & Root & Leaf & Root & Leaf & Root \\
\hline$\mu \mathrm{mol} \mathrm{L}{ }^{-1}$ of $\mathrm{Al}^{3+}$ & ---. & & & $\mathrm{kg}^{-1}$ & & ----- \\
\hline 13.3 & 3.42 & 5.27 & 30.31 & 14.36 & 7.53 & 5.56 \\
\hline 35.3 & 2.85 & 6.71 & 31.71 & 12.82 & 7.14 & 5.75 \\
\hline 90.0 & 2.26 & 5.73 & 28.32 & 10.75 & 6.71 & 5.46 \\
\hline 153.3 & 1.97 & 5.49 & 25.06 & 9.26 & 5.27 & 4.12 \\
\hline 220.7 & 1.63 & 5.58 & 20.19 & 8.34 & 4.58 & 3.48 \\
\hline Mean & 2.43 & 5.76 & 27.12 & 11.10 & 6.25 & 4.87 \\
\hline F test & $* *$ & ns & $* *$ & $* *$ & $* *$ & $*$ \\
\hline Regression & $\mathrm{L}$ & ns & $\mathrm{L}$ & $\mathrm{L}$ & $\mathrm{L}$ & $\mathrm{L}$ \\
\hline CV (\%) & 9.4 & 12.6 & 8.7 & 9.2 & 6.4 & 8.8 \\
\hline
\end{tabular}

ns: not significant. $*$ and $* *$ : statistical significance at $5 \%$ and $1 \%$, respectively, by $\mathrm{F}$ test. $1 \%$. L: linear equation. CV: coefficient of variation.

Source: Elaboration of the authors.

Table 2. Effects of aluminum activity in nutrient solution on the aluminum content and accumulation of the leaves, stems and roots of young physic nut (Jatropha curcas L.) plants. Data refer to mean values $(\mathrm{n}=5)$.

\begin{tabular}{|c|c|c|c|c|c|c|}
\hline \multirow{2}{*}{ Aluminum activity } & \multicolumn{3}{|c|}{ Aluminum content } & \multicolumn{3}{|c|}{ Aluminum accumulated } \\
\hline & Leaf & Stem & Root & Leaf & Stem & Root \\
\hline$\mu \mathrm{mol} \mathrm{L}{ }^{-1}$ of $\mathrm{Al}^{3+}$ & \multicolumn{3}{|c|}{------- $\mathrm{mg} \mathrm{kg}^{-1}$} & \multicolumn{3}{|c|}{ - - } \\
\hline 13.3 & 46.8 & 13.5 & 890 & $2.35(7.8)^{\dagger}$ & $0.44(1.5)$ & $27.4(90.8)$ \\
\hline 35.3 & 162.9 & 60.9 & 5.728 & $7.81(6.7)$ & $1.79(1.5)$ & $107.4(91.8)$ \\
\hline 90.0 & 199.5 & 80.5 & 6.575 & $7.80(7.4)$ & $1.62(1.5)$ & $95.3(91.0)$ \\
\hline 153.3 & 302.9 & 179.7 & 7.398 & $6.92(6.3)$ & $2.38(2.2)$ & $100.0(91.5)$ \\
\hline 220.7 & 425.3 & 316.9 & 8.521 & $5.87(5.1)$ & $2.99(2.6)$ & $106.5(92.3)$ \\
\hline Mean & 227.5 & 130.3 & 5.822 & $6.15(6.4)$ & $1.84(1.9)$ & $87.3(91.6)$ \\
\hline F test & $* *$ & $* *$ & $* *$ & $*$ & $* *$ & $* *$ \\
\hline Regression & $\mathrm{L}$ & $\mathrm{L}$ & Q & Exp & $\mathrm{L}$ & Exp \\
\hline $\mathrm{CV}(\%)$ & 13.7 & 11.5 & 9.6 & 14.8 & 11.5 & 18.5 \\
\hline
\end{tabular}

$*$ and **: statistical significance at $5 \%$ and $1 \%$, respectively, by $\mathrm{F}$ test. L: linear equation. Q: quadratic equation. Exp: exponential equation. $\mathrm{CV}$ : coefficient of variation.

${ }^{\dagger}$ Values in parentheses represent the percentage of $\mathrm{Al}$ accumulated in each part of the plant (leaf, stem and root) in relation to the total amount accumulated in the plant.

Source: Elaboration of the authors. 
Increased active $\mathrm{Al}^{3+}$ in solution reduced the $\mathrm{Ca}$ and $\mathrm{Mg}$ contents in leaves and roots of physic nut (Table 1). There was an average reduction in $\mathrm{Ca}$ and $\mathrm{Mg}$ content of $33 \%$ and $39 \%$ in leaves, and $42 \%$ and $37 \%$ in roots, respectively, when comparing the plants exposed to 13.3 and $220.7 \mu \mathrm{mol} \mathrm{L} \mathrm{L}^{-1}$ of $\mathrm{Al}^{3+}$. The lower $\mathrm{Ca}$ and $\mathrm{Mg}$ content in plant tissues in the presence of $\mathrm{Al}$ is due to both ions competing for binding with $\mathrm{Al}$ to the active site of ion channels involved in the absorption process (MALAVOLTA; VITTI; OLIVEIRA, 1997). However, inhibition of $\mathrm{Ca}^{2+}$ and $\mathrm{Mg}^{2+}$ influx into the cell by $\mathrm{Al}^{3+}$ is rapid and reversible. The $\mathrm{Ca}^{2+}$ channels in the plasma membrane of root cells are very sensitive to Al. This block may be involved in Al toxicity to plants, and it may contribute to a disruption of intracellular $\mathrm{Ca}^{2+}$ homeostasis (KOCHIAN; HOEKENGA; PIÑEROS, 2004).

Aluminum content was highest in roots, followed by leaves and stems (Table 2). Increasing levels of active $\mathrm{Al}^{3+}$ in solution led to increased $\mathrm{Al}$ content in leaves, stems and roots of physic nut plants (Table 2). Al accumulation in leaves, stems and roots was similar in all Al treatments, differing significantly only from the treatment without addition of metal.

Aluminum accumulated preferentially in the root system of physic nut plants (Table 2). On average, only $8.3 \%$ of total $\mathrm{Al}$ accumulated by plants was transported to the shoot - long-distance transport. These results confirm the general finding that $\mathrm{Al}$ accumulation occurs preferentially in the root system of plants (MASSOT; POSCHENRIEDER; BARCELÓ, 1992; MATTIELLO et al., 2008). This accumulation may explain the deleterious effect of $\mathrm{Al}$ on the growth of the physic nut roots reported in this study. The retention of $\mathrm{Al}$ in the roots, preventing its transport to the shoot of the plant, can be an important factor for Al tolerance in plants, by preventing the deleterious effects of this metal in other organs.

\section{Conclusions}

Physic nut shoot and root growth progressively decreased with increasing $\mathrm{Al}^{3+}$ activity in solution, and plants showed morphological abnormalities typical of injury caused by this metal at the two highest Al levels.

Increasing active $\mathrm{Al}^{3+}$ levels reduced $\mathrm{P}$ concentrations in leaves, and $\mathrm{Ca}$ and $\mathrm{Mg}$ in leaves and roots of physic nut, demonstrating the effect of Al on the uptake, transport and use of these nutrients by plants.

Aluminum accumulated preferentially in the roots of physic nut, whereas only a small amount was transported to shoots.

\section{References}

ARRUDA, F. P.; BELTRÃO, N. E. M.; ANDRADE, A. P.; PEREIRA, W. E.; SEVERINO, L. S. Cultivo de pinhão-manso (Jatropha curcas L.) como alternativa para o semi-árido nordestino. Revista Brasileira de Oleaginosas e Fibrosas, Campina Grande, v. 8, n. 1, p. 789-799, 2004.

BARCELÓ, J.; POSCHENRIEDER, C. Fast root growth responses, root exudates and internal detoxification as clues to the mechanisms of aluminum toxicity and resistance: a review. Environmental and Experimental Botany, Oxford, v. 48, n. 1, p. 75-92, 2002.

BEUTLER, A. N.; FERNANDES, L. A.; FAQUIN, V. Efeito do alumínio sobre o crescimento de duas espécies florestais. Revista Brasileira de Ciência do Solo, Viçosa, v. 25, n. 4, p. 923-928, 2001.

BRACCINI, M. C. L.; MARTINEZ, H. E. P.; PEREIRA, P. R. G.; SAMPAIO, N. F.; SILVA, E. A. M. Tolerância de genótipos de cafeeiro ao $\mathrm{Al}$ em solução nutritiva. I. Crescimento e desenvolvimento da parte aérea e sistema radicular. Revista Brasileira de Ciência do Solo, Viçosa, v. 22, n. 3, p. 435-442, 1998a.

BRACCINI, M. C. L.; MARTINEZ, H. E. P.; PEREIRA, P. R. G.; SAMPAIO, N. F.; PEREIRA, A. A. Tolerância de genótipos de cafeeiro ao $\mathrm{Al}$ em solução nutritiva. II. Teores de P, Ca e Al e eficiência ao P e Ca. Revista Brasileira de Ciência do Solo, Viçosa, v. 22, n. 3, p. 443450, $1998 \mathrm{~b}$. 
DANTAS, A. C. M.; FORTES, G. R. L.; SILVA, J. B.; NEZI, A. N.; RODRIGUES, A. C. Tolerância ao alumínio em porta-enxertos somaclonais de macieira cultivados em solução nutritiva. Pesquisa Agropecuária Brasileira, Brasília, v. 36, n. 4, p. 615-623, 2001.

FRANCIS, G.; EDINGER, R.; BECKER, K. A concept for simultaneous wasteland reclamation, fuel production, and socio-economic development in degraded areas in India: need, potential and perspectives of Jatropha plantations. Nature Resources Forum, Oxford, v. 29, n. 1, p. 12-24, 2005.

GIANNAKOULA, A.; MOUSTAKAS, M.; MYLONA, P.; PAPADAKIS, I.; YUPSANIS, T. Aluminum tolerance in maize is correlated with increased levels of mineral nutrients, carbohydrates and proline, and decreased levels of lipid peroxidation and $\mathrm{Al}$ accumulation. Journal of Plant Physiology, Stuttgart, v. 165, n. 4, p. 385-396, 2008.

GUSTAFSSON, J. P. Visual MINTEQ: version 3.0. Online. 2012. Disponível em: $<$ http://www.lwr.kth.se/ English/OurSoftware/Vminteq.>. Acesso em: 10 maio 2012.

HARTWIG, I.; OLIVEIRA, A. C.; CARVALHO, F. I. F.; BERTAN, I.; SILVA, J. A. G.; SCHMIDT, D. A. M.; VALÉRIO, I. P.; MAIA, L. C.; FONSECA, D. A. R.; REIS, C. E. S. Mecanismos associados à tolerância ao alumínio em plantas. Semina: Ciências Agrárias, Londrina, v. 28, n. 2, p. 219-228, 2007.

HOAGLAND, D. R.; ARNON, D. I. The water culture method for growing plants without soils. Berkeley: California Agricultural Experimental Station, 1950. 347 p.

KING, A. J.; HE, W.; CUEVAS, J. A.; FREUDENBERGER, M.; RAMIARAMANANA, D.; GRAHAM, I. A. Potential of Jatropha curcas as a source of renewable oil and animal feed. Journal of Experimental Botany, Oxford, v. 60, n. 10, p. 2897-2905, 2009.

KOCHIAN, L. V.; HOEKENGA, O. A.; PIÑEROS, M. A. How do crop plants tolerate acid soils? Mechanisms of aluminum tolerance and phosphorous efficiency. Annual Review of Plant Biology, Palo Alto, v. 55, n. 1, p. 459-493, 2004.

KUMAR, A.; SHARMA, S. An evaluation of multipurpose oil seed crop for industrial uses (Jatropha curcas L.): a review. Industrial Crops and Products, Amsterdam, v. 28, n, 1, p. 1-10, 2008.

LAVIOLA, B. G.; DIAS, L. A. S. Teor e acúmulo de nutrientes em folhas e frutos de pinhão-manso. Revista Brasileira de Ciência do Solo, Viçosa, v. 32, n. 5, p. 1969-1975, 2008.
LIMA, R. L. S.; SEVERINO, L. S.; FERREIRA, G. B.; SILVA, M. I. L.; ALBUQUERQUE, R. C.; BELTRÃO, N. E. M. Crescimento da mamoneira em solo com alto teor de alumínio na presença e ausência de matéria orgânica. Revista Brasileira de Oleaginosas e Fibrosas, Campina Grande, v. 11, n. 1, p. 15-21, 2007.

LÓPEZ-BUCIO, L.; NIETO-JACOBO, M. F.; RAMIREZ-RODRIGUES, V.; HERRARA-ESTELLA, L. Organic acids metabolism in plants: from adaptive physiology to transgenic varieties for cultivation in extreme soils. Plant Science, Saint Louis, v. 160, n. 1, p. $1-13,2000$.

MACEDO, F. L.; PEDRA, W. N.; SILVA, S. A.; BARRETO, M. C. V.; SILVA-MANN, R. Efeito do alumínio em plantas de pinhão-manso (Jatropha curcas L.), cultivadas em solução nutritiva. Semina: Ciências Agrárias, Londrina, v. 32, n. 1, p. 157-164, 2011.

MACKLON, A. E. S.; SIM, A. Modifying effects of a non-toxic level of aluminium on phosphate fluxes and compartmentation in root cortex cells of intact ryegrass seedlings. Journal of Experimental Botany, Oxford, v. 43, n. 11, p. 1483-1490, 1992.

MALAVOLTA, E.; VITTI, G. C.; OLIVEIRA, S. A. Avaliação do estado nutricional das plantas: princípios e aplicações. Piracicaba: Potafos, 1997. 319 p.

MASSOT, N.; POSCHENRIEDER, C.; BARCELÓ, J. Differential response of three bean (Phaseolus vulgaris L.) cultivars to aluminum. Acta Botanica Neerlandica, Stuttgart, v. 41, n. 2, p. 293-298, 1992.

MATTIELlO, E. M.; PEREIRA, M. G.; ZONTA, E.; MAURI, J.; MATIELLO, J. D.; MEIRELES, P. G.; SILVA, I. R. Produção de matéria seca, crescimento radicular e absorção de cálcio, fósforo e alumínio por Coffea canephora e Coffea arabica sob influência da atividade do alumínio em solução. Revista Brasileira de Ciência do Solo, Viçosa, v. 32, n. 1, p. 425-434, 2008.

McCORMICK, L. H.; BORDEN, F. Y. The occurrence of aluminum phosphate in plant roots. Soil Science Society of America Proceedings, Madison, v. 38, n. 6, p. 931933, 1974.

MENGEL, K.; KIRKBY, E. A. Principles of plant nutrition. $5^{\text {th }}$ ed. Dordrecht, Kluwer: Academic Publishers, 2001. 849 p.

MIYAZAWA, M.; PAVAN, M.A.; MURAOKA, T.; CARMO, C. A. F. S.; MELLO, W. J. Análises químicas de tecido vegetal. In: SILVA, F. C. Manual de análises químicas de solos, plantas e fertilizantes. Brasília: Embrapa, 1999. 370 p. 
PAVAN, M. A.; BINGHAN, F. T. Toxidez de alumínio em cafeeiros cultivados em solução nutritiva. Pesquisa Agropecuária Brasileira, Brasília, v. 17, n. 9, p. 12931302, 1982.

SAMAC, D. A.; TESFAYE, M. Plant improvement for tolerance to aluminum in acid soils: a review. Plant Cell Tissue and Organ Culture, Dordrecht, v. 75, n. 3, p. 189207, 2003.

SÁNCHEZ, P. A.; SALINAS, J. G. Low-input technologies for managing oxisols and ultisols in tropical America. Advances in Agronomy, New York, v. 34, n. 1, p. 279-406, 1981.
SEVERINO, S. L.; VALE, L. S.; BELTRÃO, M. E. D. A simple method for measurement of Jatropha curcas leaf area. Revista Brasileira de Oleaginosas e Fibrosa, Campina Grande, v. 11, n. 1, p. 9-14, 2007.

SOUZA, P. T.; SILVA, E. B.; GRAZZIOTTI, P. H.; FERNANDES, L. A. NPK fertilization on initial growth of physic nut seedlings in Quartzarenic Neossol. Revista Brasileira de Ciência do Solo, Viçosa, v. 35, n. 2, p. 559566, 2011.

TECCHIO, M. A.; PIRES, E. J. P.; TERRA, M. M.; GRASSI FILHO, H.; CORRÊA, J. C.; VIEIRA, C. R. Y. I. Tolerância de porta-enxertos de videira cultivados, em solução nutritiva, ao alumínio. Revista Ceres, Viçosa, v. 53, n. 306, p. 243-250, 2006. 